\title{
Reduced Tim-3 expression on HTLV-I Tax-specific cytotoxic T lymphocytes in HTLV-I infection
}

\author{
Nashwa H Abdelbary ${ }^{1}$, Hazem M Abdullah', Toshio Matsuzaki², Daisuke Hayashi², Yuetsu Tanaka ${ }^{3}$ \\ Hiroshi Takashima², Shuji Izumo', Ryuji Kubota ${ }^{1 *}$ \\ From 15th International Conference on Human Retroviruses: HTLV and Related Viruses \\ Leuven and Gembloux, Belgium. 5-8 June 2011
}

T-cell immunoglobulin and mucin domain-containing molecule-3 (Tim-3) and programmed cell death-1 (PD1) are $\mathrm{T}$-cell exhaustion molecules. We investigated the expression of Tim-3 and PD-1 in HTLV-I infection. Tim-3 expression, but not PD-1 expression, was reduced on CD4+ and CD8+ T cells of HAM/TSP patients and HTLV-I carriers as compared to healthy controls. Tim-3 expression was also reduced in HTLV-I Tax-specific cytotoxic T lymphocytes (CTLs) as compared to cytomegalovirus-specific CTLs. Tim-3+, but not PD-1+, Tax-specific CTLs produced less interferon- $\gamma$ and exhibited low cytolytic activity. However, we observed no difference in the expression of Tim-3 or cytolytic activity between Tax-specific CTLs of HAM/TSP patients or carriers. Moreover, HTLV-I-infected CD4+ T cells showed decreased Tim-3 expression. The decreased expression of Tim-3 in HTLV-I infection is a marked contrast to other chronic viral infections such as HIV and HCV infection, where Tim-3 expression is increased in $\mathrm{T}$ cells, including the virus-specific CTLs. In HTLV-I infection, CTL response may not be negatively regulated by Tim-3. Rather, immune cells such as HTLV-I-specific CTLs may be resistant to cell death through the Tim-3/ galectin- 9 pathway. In summary, our data suggest that Tim-3 expression is reduced in HTLV-I infection and that a high number of Tim-3- HTLV-I-specific CTLs preserves their cytolytic activity, thereby controlling viral replication.

\section{Author details}

${ }^{1}$ Center for Chronic Viral Diseases, Kagoshima University, Kagoshima 8908544, Japan. ${ }^{2}$ Department of Neurology and Geriatrics, Kagoshima University,

\footnotetext{
* Correspondence: kubotar@m2.kufm.kagoshima-u.ac.jp

${ }^{1}$ Center for Chronic Viral Diseases, Kagoshima University, Kagoshima 8908544, Japan

Full list of author information is available at the end of the article
}

Kagoshima 890-8544, Japan. ${ }^{3}$ Department of Immunology, University of the Ryukyus, Nishihara-cho, Okinawa 903-0215, Japan.

Published: 6 June 2011

doi:10.1186/1742-4690-8-S1-A112

Cite this article as: Abdelbary et al:: Reduced Tim-3 expression on HTLVI Tax-specific cytotoxic T lymphocytes in HTLV-I infection. Retrovirology 2011 8(Suppl 1):A112.
Submit your next manuscript to BioMed Central and take full advantage of:

- Convenient online submission

- Thorough peer review

- No space constraints or color figure charges

- Immediate publication on acceptance

- Inclusion in PubMed, CAS, Scopus and Google Scholar

- Research which is freely available for redistribution

Submit your manuscript at www.biomedcentral.com/submit
( Biomed Central
C Biomed Central

(c) 2011 Abdelbary et al; licensee BioMed Central Ltd. This is an open access article distributed under the terms of the Creative Commons Attribution License (http://creativecommons.org/licenses/by/2.0), which permits unrestricted use, distribution, and reproduction in any medium, provided the original work is properly cited. 